\title{
Design of a Handicraft Product Marketplace using a Web-Based Business to Consumer (B2C) Method
}

\author{
M. Fajri Hermawan \\ Universitas Putra Indonesia "YPTK" Padang, Indonesia \\ fajrigepuk69@gmail.com
}

\begin{abstract}
West Sumatra is famous for its embroidery. Usually embroidery is found on mukena, hijab, brackets, koko clothes, and others. The issue of marketing and brand promotion is still one of the biggest obstacles for embroidery businesses in increasing their business scale. Embroidery business actors often experience problems in selling their products. This cannot be separated from the tendency of these business actors to focus more on the production process without being balanced by marketing and promotion. Some embroiders, when the goods are available, they are confused about what to do to sell it quickly. As a result, the marketing and promotion steps taken tend to be conventional, namely word of mouth or simply displaying their products in stores. To overcome these problems, the authors conducted research to design a marketplace application to help business people to easily promote their products. In conducting this research the author uses the SDLC method. While the development of software in the design of this decision support system the author uses the PHP programming language. The results of this study are a marketplace application that can make it easier for customers to access products without having to come to the place, make purchases, transfer payments or online anywhere, so as to increase customer buying interest.
\end{abstract}

Keywords: Marketplace, Marketing, Embroidery, PHP, WEB.

\section{Introduction}

Technology and communication are currently developing along with the needs of each individual in various fields such as business, education, agriculture, health, and technology. The development of technology, the digital world, and the internet has had a West Sumatra is famous for its embroidery. Usually, strong impact on the world of marketing. shopping embroidery is found on, hijab, brackets, Koko clothes, online is not a foreign thing [1]. The marketing system and others. Marketing and brand promotion issues are that was originally traditional (offline) is now turning still one of the biggest obstacles for embroidery to digital (online). With the shift in shopping behavior businesses in increasing their business scale[10].[11]. from conventional shopping models (buying from Business actors often experience problems in selling sellers who have stored) to virtual shopping models their products. This cannot be separated from the mediated by websites via the internet [2]. The level of tendency of these business actors to focus more on the competition in business requires every marketer to be production process without marketing and promotion. able to carry out marketing activities more effectively Some embroider, when the goods are available, are and efficiently. In order to be able to keep the product confused about what to do to sell it quickly[12]. As a in demand by customers, try to think creatively and result of the marketing and promotion steps taken for innovatively in developing the business[3],[4],[5]. The conventional, namely word of mouth or displaying brand of a product can be superior if the organization is products in stores. To help embroiderers, it is better to able to attract consumers to direct its brand. With many design online sales and marketing media, so that actors online sales media. At this time like social media and can easily promote their products.

Star up, we are also developing sales using the marketplace[6],[7].

The marketplace is an internet-based online media (web-based) where business activities and transactions are carried out between buyers and sellers with an online business model that helps promote merchandise. Transactions that occur in the marketplace are managed

\section{Research Method}

So that in writing this report it is focused and inseparable from data and information[13].[14]. In order for this thesis to be focused and inseparable from data and information related to the subject of discussion, the author uses several research methods to obtain these data. 


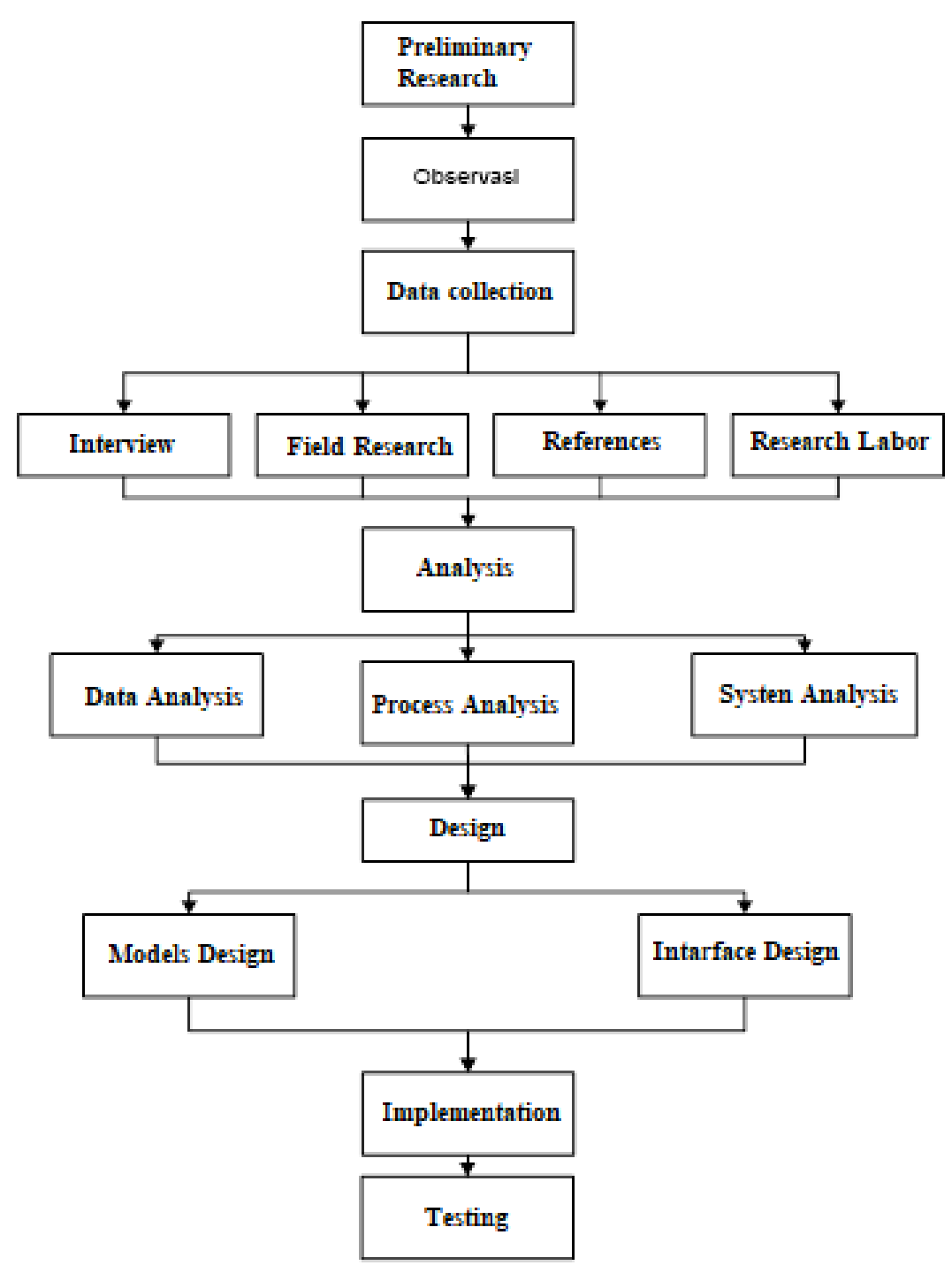

Fig. 1 Research Framework

Figure. 1 Explain the stages of the research carried out. the city where the shop is located, so the monthly sales Stages of research begins with determining the problem volume has not shown good results. satisfying. until the discussion to find a solution. The marketplace design process is determined by starting data analysis, system design and at the final stage the resulting system will be tested before being implemented.

\section{Result and Discussion}

Next is the system design stage, which is the stage that is passed in designing a system such as determining the needs of the system, database design, modeling, and designing the system display. The designs carried out to create a marketplace-based system include:

After observing the West Sumatra Embroidery A. Swallow the amount related to the product to be Handicraft Shop on the system running at the West sold, namely product name, product price, product Sumatra Embroidery Handicraft Shop, currently, the stock made in one day, product images, and other sales and product introduction system still does not use information such as profiles of business owners, a website media that allows selling and marketing employees, duties, each employee, complete address of products online. Currently, customers have to come the place of business and account number used to directly to see the product and then make a transaction receive customer money transfers.

for the selected product. To serve customers directly, the West Sumatra Embroidery Handicraft Shop operates only during business hours so that customers

B. Making the system flow using UML to find out the stages of the process in the system.

have limited time, the marketing area of the West C. Creating a database for the website itself. The Sumatra Embroidery Handicraft Shop is only around website consists of two, namely for the admin and for 
the customer. The website admin is made to manage The system testing stage aims to measure the data that goes to website customers, for example, to performance of the system in handling the performance manage product management, member management, of a predetermined task[18]. System measurement category management, comment management, and so results can be seen based on the performance of the on. system logic to the display presented to the user[19]. In

\subsection{Use Case Diagram Model Design}

Use case diagrams can be used during the analysis this case, the testing can be seen as follows:

process to capture requirements or requests for a sales The main page is the page that first appears when the system and to understand how the system should user opens the marketplace on West Sumatra work[15],[16].[17]. as for the form of usecase diagram Embroidery Handicrafts. This main page contains design can be seen in Fig. 2.

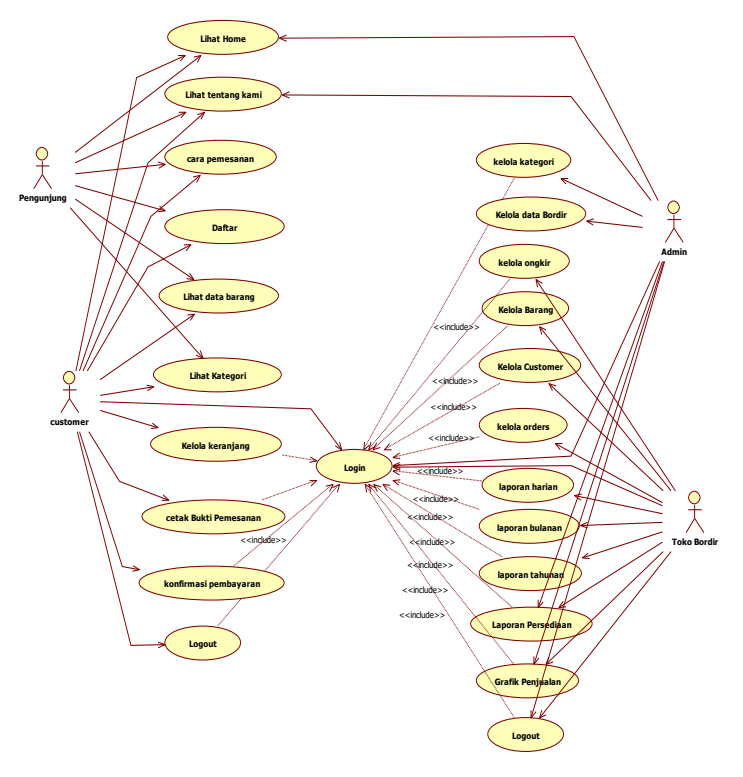

Fig. 2 Use Case Diagram

\subsection{Class Diagram Model Design}

Class Diagram of the West Sumatran Embroidery Handicraft Shop marketplace which is depicted as Figure. 3.

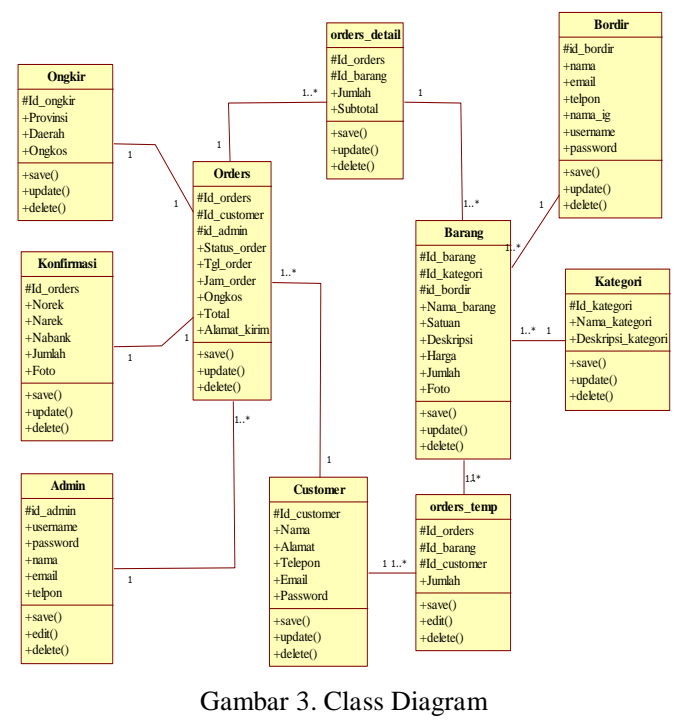

3.3 System Test menus that can be accessed by the user as shown in Figure. 4.

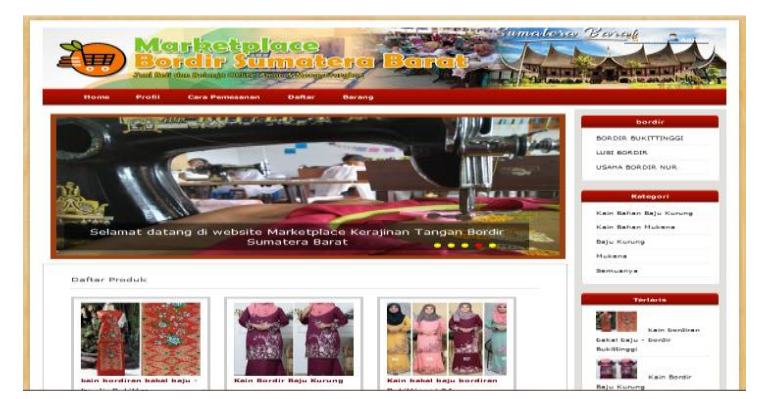

Fig. 4 Main Page System

\section{B. Customer List Page}

The list page is the page that is used to become a member in the West Sumatra Embroidery Handicrafts marketplace as shown in Figure. 5.

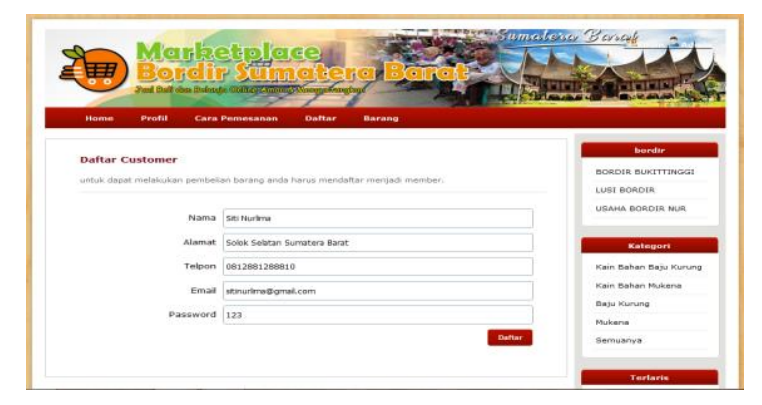

Fig. 5 Customer List Page

\section{Customer Login Page}

The login page is the page used to enter the West Sumatra Embroidery Handicrafts marketplace as shown in Figure. 6.

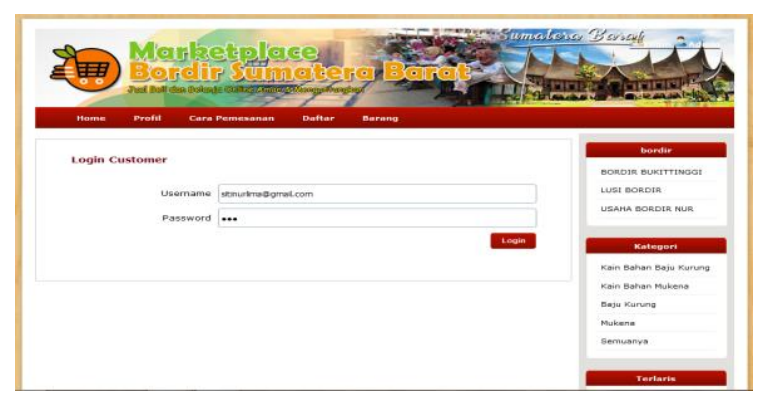

Gambar 6. Customer Login Page

D. Goods Order Process Page

Journal of Computer Science and Information Technology Volume 8 Issue 8 (2022) 7-11 
Users or customers can order goods by selecting the 4. Conclusion item menu and selecting the desired item as shown in Figure. 7.

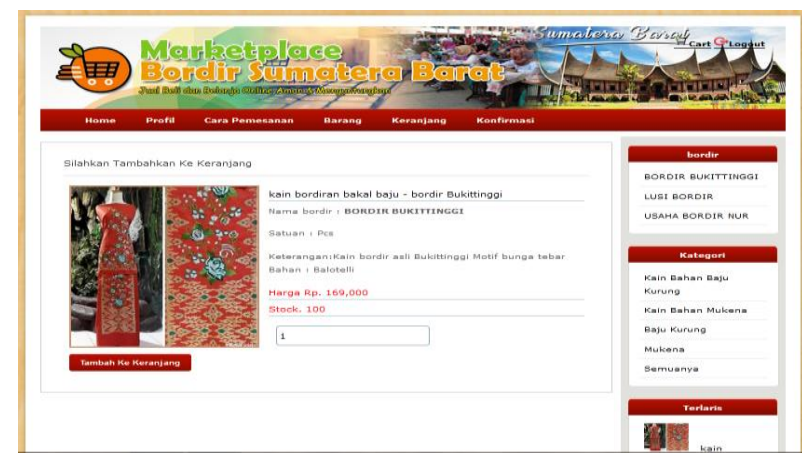

Fig. 7 Goods Order Process Page

E. Proof of Order of Goods

To be able to see proof of ordering goods, the customer clicks the confirmation menu. Then the customer will choose a list of orders to be printed, a proof of ordering goods will appear as shown in Figure. 8 .

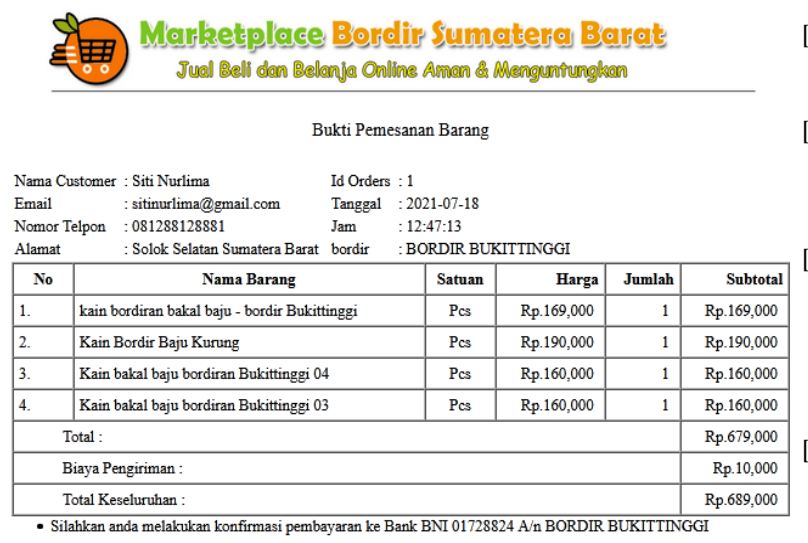

Fig. 7 Proof of Order of Goods

\section{F. Sales Chart}

To be able to see the sales graph, the Admin clicks the menu graph. Then the admin will be asked to fill in the year of the report and clicking the print button will display a graph of the sale of goods as shown in Figure. 8.

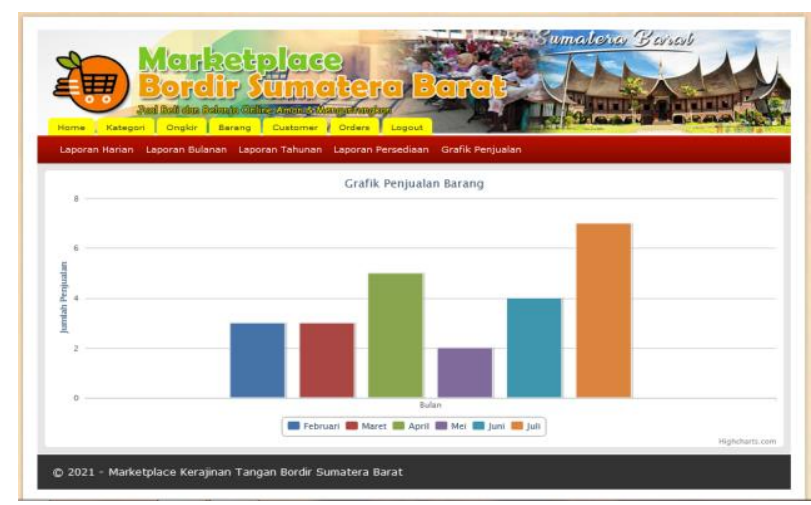

Fig. 7 Sales Chart
Based on the analysis and discussion that has been carried out in the previous chapter, several conclusions are obtained, namely that the existence of a handicraft marketplace application in West Sumatra can be used as a community marketing portal that facilitates the marketing of embroidery handicrafts in West Sumatra. With the marketplace application, it is easier for customers to access detailed product information in order to increase customer satisfaction and ease in viewing the product information they want. With this web-based marketplace application designer, it can make it easier for customers to access products without having to come on time, make purchases, transfer payments or online, so as to increase customer buying interest.

\section{References}

[1] Andini, Silfia Andini. (2017). "Perancangan Dan Implementasi Supply Chain Management (SCM) Pada CV Hayati Padang." $\begin{array}{llll}\text { Edik Informatika } & 3 & \text { (1): } & \end{array}$ https://doi.org/10.22202/ei.2016.v3i1.1514.

[2] Andini, S., \& Pratiknyo,L. (2018). Perancangan Dan Implementasi Supply Chain Management (SCM) Pada CV Hayati Padang. Jurnal Edik Informatika ISSN : 2407-0491.

[3] Anisya \& Allazi, E. (2017). Rekayasa Perangkat Lunak Penjadwalan dan Pemesanan Iklan Radio (Studi Kasus : Radio Classy FM). Jurnal CoreIT, Vol.3, No.2, Desember 2017 ISSN 2460-738X

[4] Anthony, A., Tanaamah, A. R., \& Wijaya, A. F. (2017) Analisis Dan Perancangan Sistem Informasi Penjualan Berdasarkan Stok Gudang Berbasis Client Server (Studi Kasus Toko Grosir "Restu Anda”). Jurnal Teknologi Informasi Dan Ilmu Komputer, 4(2),136. https://doi.org/10.25126/jtiik.201742321

[5] Ashari, Ayu Nandita, and Ratna Mutu Manikam. (2019). "Analisa Dan Perancangan Marketplace Bahan Bangunan Berbasis Website Pendahuluan Studi Literatur Metodologi” 1 (3): 84-92.

[6] Harminingtyas, R. (2014). Analisis Layanan Website Sebagai Media Promosi, Media Transaksi dan Media Informasi dan Pengaruhnya Terhadap Brand Image Perusahaan Pada Hotel Ciputra di Kota Semarang. JURNAL STIE SEMARANG, VOL 6, NO 3, Edisi Oktober 2014

[7] Andini, Silfia Andini. (2017). "Perancangan Dan Implementasi Supply Chain Management (SCM) Pada CV Hayati Padang." $\begin{array}{llll}\text { Edik Informatika } \quad 3 & \text { (1): }\end{array}$ https://doi.org/10.22202/ei.2016.v3i1.1514.

[8] Andini, S., \& Pratiknyo,L. (2018). Perancangan Dan Implementasi Supply Chain Management (SCM) Pada CV Hayati Padang. Jurnal Edik Informatika ISSN : 2407-0491

[9] Anisya \& Allazi, E. (2017). Rekayasa Perangkat Lunak Penjadwalan dan Pemesanan Iklan Radio (Studi Kasus : Radio Classy FM). Jurnal CoreIT, Vol.3, No.2, Desember 2017 ISSN 2460-738X

[10] Anthony, A., Tanaamah, A. R., \& Wijaya, A. F. (2017). Analisis Dan Perancangan Sistem Informasi Penjualan Berdasarkan Stok Gudang Berbasis Client Server (Studi Kasus Toko Grosir "Restu Anda"). Jurnal Teknologi Informasi Dan $\begin{array}{lll}\text { Ilmu } \quad \text { Komputer, } & 4(2),\end{array}$ https://doi.org/10.25126/jtiik.201742321

111] Ashari, Ayu Nandita, and Ratna Mutu Manikam. (2019). "Analisa Dan Perancangan Marketplace Bahan Bangunan Berbasis Website Pendahuluan Studi Literatur Metodologi" 1 (3): 84-92.

[12] Harminingtyas, R. (2014). Analisis Layanan Website Sebagai Media Promosi, Media Transaksi dan Media Informasi dan Pengaruhnya Terhadap Brand Image Perusahaan Pada Hotel

Journal of Computer Science and Information Technology Volume 8 Issue 8 (2022) 7-11 
Ciputra di Kota Semarang. JURNAL STIE SEMARANG, VOL 6, NO 3, Edisi Oktober 2014

[13] Hermawan, R., Hidayat, A., \& Utomo, V. G. (2015). Sistem Informasi Penjadwalan Kegiatan Belajar Mengajar Berbasis Web (Studi Kasus: Yayasan Ganesha Operation Semarang). Jurnal Evolusi, 3(2), 1-8.

[14] Iswandy, E. (2016). Analisa Dan Perancangan Sistem Informasi Penagihan Purchasing Order Customer Studi Kasus Dalam Cv. Vertical Cipta Relasi Dalamng Dengan Metode Centralized Data Processing. Jurnal TEKNOIF, 4(Oktober), 14.

[15] Kadir, A. (2013). Pengenalan Sistem Informasi. Andi.

[16] Mardison. (2017). Perancangan Sistem Informasi Inventory Dalam Alinia Mart Berbasis Multi User Dengan Java Netbeans

Dan Mysql. Majalah Ilmiah Upi Yptk, 24(2), 2. http://lppm.upiyptk.ac.id/majalahilmiah/index.php/majalahilmi ah/article/view/95

[17] Mujab, Syariful, Kodrat Iman Satoto, and Kurniawan Teguh Martono. (2014). "Perancangan Sistem Informasi Akademik Berbasis Mobile Web Studi Kasus Di Program Studi Sistem Komputer Universitas Diponegoro.” Jurnal Teknologi Dan Sistem Komputer 2 